Fiscal Reforms, Fiscal Rule and Development Spending: How Indian States have Performed?

Pinaki Chakraborty and Bharatee Bhusana Dash

Working Paper No. 2013-122

April 2013

National Institute of Public Finance and Policy New Delhi http://www.nipfp.org.in 


\title{
Fiscal Reforms, Fiscal Rule and Development Spending: How Indian States have Performed?
}

\author{
Pinaki Chakraborty* \\ and \\ Bharatee Bhusana Dash
}

\begin{abstract}
The influence of business cycle on fiscal balance is well-documented in literature ${ }^{1}$. However, the responsibility of fiscal management of a country cannot be entirely left to be determined by the business cycle. As a result, in the recent times, various countries have introduced interventionist fiscal rules to manage their fiscal situation. Fiscal rules are usually designed according to a country's requirements and, often, prepared by aiming at addressing specific fiscal issues in a country. In addition to this, how successful would fiscal rules be in serving their purpose largely depends on effective implementation of such rules and also on the behavior of the business cycle. But it is primarily an empirical question. ${ }^{2}$
\end{abstract}

Both cross-country and country-specific empirical studies have been carried out to check the effectiveness of fiscal rules in practice. The major cross-country studies attempted in this regard are by: Gali and Perotti (2002), Ballabriga and Martinez-Mongay (2003) and Marneffe (2011) for the European Union; Viren (2002) for OECD countries; and Tapsoba (2012) for 74 developing countries. By and large, these studies found that fiscal rules have been quite successful in serving their purpose. To address countryspecific issues, Alesina and Bayoumi (1996), Milesi-Ferretti (1996), Poterba (1997), and Auerbach (2008) for the US; Millar (1997) for Canada; Clayes (2008) for Sweden; and Dupont and Kwarteng (2012) for the UK have examined the impact of fiscal rule on fiscal balance. The literature on the impact of fiscal rules on the fiscal policies of the emerging

\footnotetext{
* Authors are respectively Professor and Economist at National Institute of Public Finance and Policy, New Delhi. An earlier version of this paper was presented at the NIPFP conference on Papers in Public Economics held on 7-8 November 2012. A revised version of this paper was also presented in the conference on Economic Theory and Policy held on 20-22 March, 2013 at NIPFP, New Delhi. We are grateful to Anjan Mukherji, S. Subramanian, Abhirup Sarkar, Vivekananda Mukherjee R Kavita Rao and other participants at these two conferences for their observations and comments. Usual disclaimer applies.

Email: pinaki.chakraborty@nipfp.org.in .

1 See Lane (2003) and Lee and Sung (2007) for the review of this literature.

2 See Kopits (2001) for an excellent review of country-specific experiences with fiscal rules.
} 
economies has been scanty. A country-specific analysis instead of a cross-country analysis would be more useful to understand how fiscal policy behaves with fiscal rules. The cross country studies ignore country-specific information and does not provide much scope for an analysis at the disaggregate level. In Indian context, the impact of fiscal reforms on fiscal balance initiated by multilateral lending institutions in selected states was examined by Rao and Chakraborty (2006). However, to the best of our knowledge, no attempt has been made to examine the impact of fiscal rule on fiscal balance in the Indian states. The other important aspect ignored by earlier studies is the path of fiscal adjustment during fiscal rule. In this paper we examine not only whether fiscal rule had favourable impact on fiscal balance but what lies behind a particular outcome in a rule based fiscal regime. Often time it is argued that fiscal targets in a rule based fiscal control regime is achieved through a cut in development and maintenance expenditure. The twin objectives of this paper are to examine the impact of fiscal rule on fiscal balance and on the path of fiscal adjustment, particularly the development spending. The focus of this study is 14 major states in India. The period of study is from 2000-01 to 2009-10.

In India, fiscal rule was introduced by most states in the fiscal year 2005-06 and a brief history of the process of rule based fiscal policy is given below. Indian federal system has witnessed an incentive based fiscal consolidation plan for the states by introducing rule based fiscal control at the instance of the Twelfth Finance Commission. The incentive structure as designed mandated that the states will be eligible for Debt Consolidation and Relief Facility (DCRF) upon enactment of Fiscal Responsibility Legislation (FRL). Except Sikkim and West Bengal, ${ }^{3}$ all other states enacted FRL to avail the DCRF facility proposed by the Twelfth Finance Commission. The Twelfth Finance Commission, by making access to the DCRF conditional upon enactment and adherence to a Fiscal Responsibility Act (FRA) by the states, introduced rule-based fiscal control at the state level that fixed the permissible level of the fiscal deficit at 3 percent of the respective state's gross state domestic product (GSDP) by 2008-09. As mentioned, this study makes an attempt to examine whether the introduction of fiscal rules has helped in bringing fiscal discipline at the subnational level in India. The study also examined how the fiscal rule has impacted on development spending at the subnational level.

This paper has been divided into following sections. In section I we discuss the fiscal imbalance profile of the centre and states and try to trace out the observed path of fiscal adjustment through a detailed analysis of the revenue and expenditure profile of the centre and states. Section II discusses the era of rule based fiscal control and the factors that led to overall fiscal consolidation during the period from 2001-02 to 2007-08. Section III discusses whether fiscal consolidation has resulted in increasing fiscal inequality in the

${ }^{3}$ Sikkim and West Bengal are two states in Indian Union. These two states also have introduced fiscal responsibility legislation to avail the conditional grants proposed by the Thirteenth Finance Commission. 
system. Section IV examines the impact of rule based fiscal control on fiscal balance and development spending. Section V draws conclusions.

\section{Path of Fiscal Adjustment}

Since 1991 economic reforms, India's path of fiscal adjustment can be grouped into 4 categories: 1. Fiscal correction through fiscal contraction: 1990-91 to 1996-97, 2. Increasing fiscal imbalance: $1997-98$ to $1999-2000$ primarily by pay revision induced increase in expenditure and falling revenues, 3. Fiscal correction without fiscal contraction: 2001-02 to 2007-08, 4. Global financial crisis induced fiscal expansion from 2008-09 onwards. Last two phases coincide with the era of rule based fiscal control. As is well known, the path of fiscal adjustment in India has not been easy. Large fiscal imbalance, which culminated into a major crisis in 1991, needed to be corrected and the structural adjustment programme initiated in 1991 put all out efforts to reduce the fiscal deficits of the central government. Also a major tax reform at the central level was initiated along with reforms in trade and industrial policy. During the early phase of reforms, if one looks at, revenue to GDP ratio declined sharply and the burden of adjustment was on the expenditure side of the budget, which resulted in a sharp reduction in capital expenditure at the central level. Discretionary cut in development spending during the early phase of fiscal reforms is well documented in the literature. However, during the initial years, reform was largely concentrated at the central level. Nothing much was done at the state level, except some moves at the margin through various memorandum of understanding (MOU) between individual states and Ministry of Finance of Government of India. During this period, various states have also signed MOU with the central government at the instance of multilateral lending institutions like Asian Development Bank and World Bank. Absence of fiscal reform at the state level became a major concern as the consolidated fiscal deficit did not decline much despite decline in centre's fiscal deficit in initial years of reform (See, figure 1). 
Figure 1: Fiscal Deficit: Centre, All States and Combined

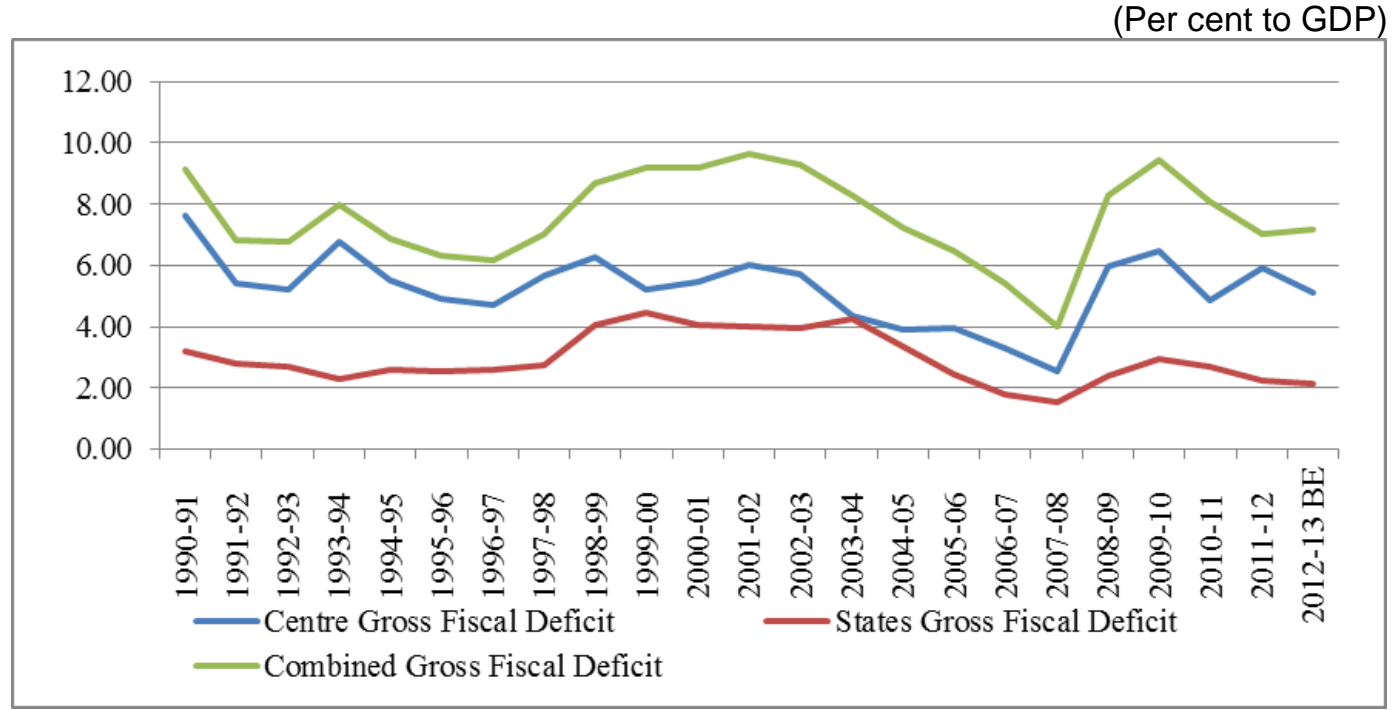

Source: 1) Handbook of Statistics on Indian Economy 2010-11, RBI.

2) State Finances: A Study of Budgets (various. issues), RBI.

As evident from figure 1, from 1996-97 onwards, there was a sharp increase in fiscal deficit at the central and state level due to the salary induced hike in expenditure at both levels of governments. At this point in time, serious concerns were raised about fiscal sustainability at the state level. However, as evident from figure 1, the situation started changing from 2000-01 onwards. There was a consistent decline in the level of deficits at both levels of government upto 2007-08. The global financial crisis and consequent fiscal expansion has again increased the level of fiscal deficits, particularly at the central level after 2007-08. The last two phases coincide with the era of rule based fiscal control. How both revenue and expenditure side of the budget behaved since the beginning of economic reform, both at the central and state level, are presented in figures 2 and 3 . As evident from figure 2, there was a sharp increase in the revenue to GDP ratio for centre and states from 2000-01 to 2007-08 and after that it started declining. This period also witnessed an increase in the aggregate expenditure to GDP ratio. But not much increased seemed to have happened at the state level when we look at figure 3. 
Figure 2: Revenue Receipts: Centre, States and Combined

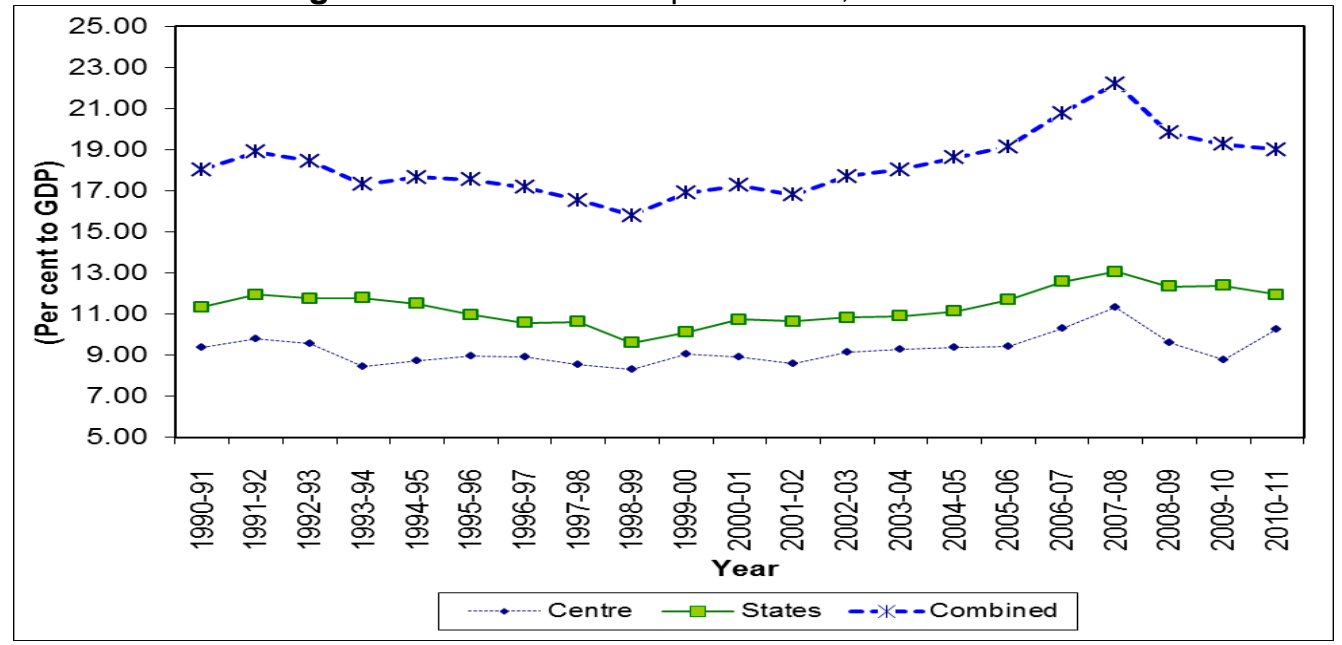

Figure 3: Total Expenditure: Centre, States and Combined

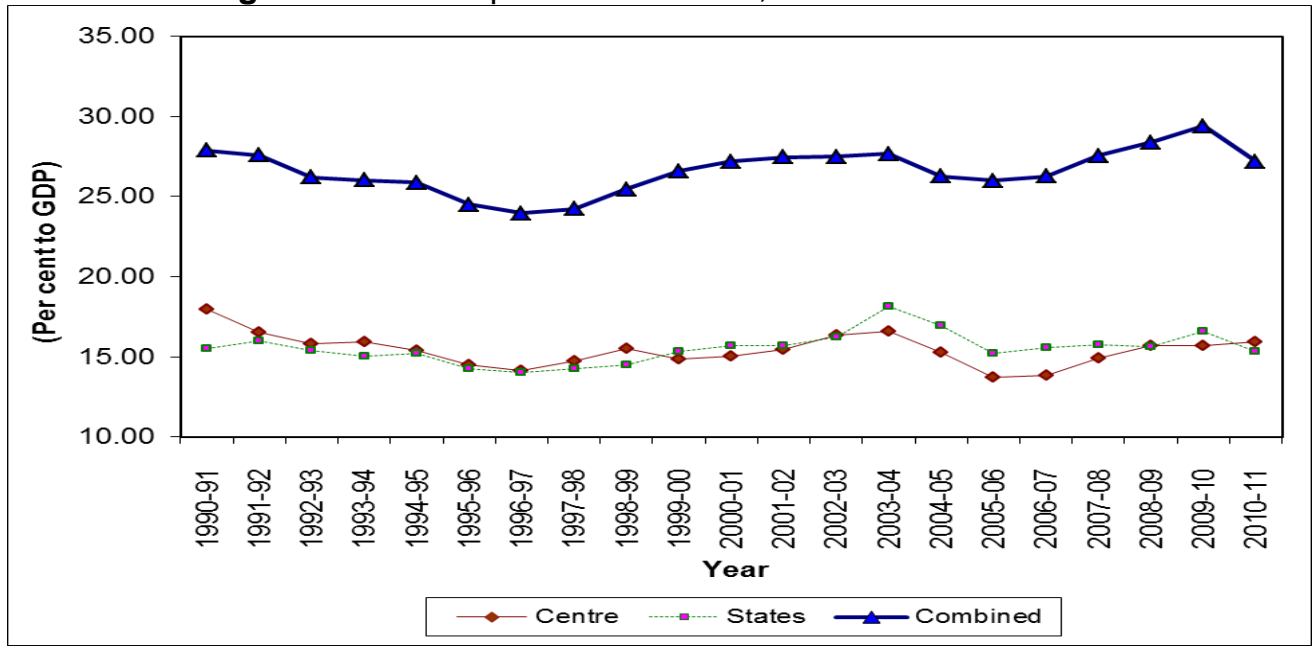

\section{The Era of Rule Based Fiscal Control}


As mentioned, unlike many other countries, India has a recent history of rule based fiscal control. The Fiscal Responsibility Act (FRA) of the Central Government was enacted in the FY 2003-04 and most of the states have enacted the Fiscal responsibility Act in the Fiscal Year 2005-06. The era of rule based fiscal control also have witnessed a sharp reduction in fiscal imbalance at the state level. This improvement in fiscal health can be characterized as intertemporal reduction in both fiscal and revenue deficits to GDP ratio and increased capital spending. States' fiscal position as evolved upto 2007-08 generated a revenue surplus and brought down the gross fiscal deficit to GDP ratio below the 3 percent FRA target. At the state level, fiscal consolidation has been achieved through higher own tax revenue mobilization, increased central devolution due to buoyant central taxes and reduction in revenue expenditure to GSDP ratio primarily due to the decline in economic and social services expenditures and interest burden. ${ }^{4}$ It is argued that improved fiscal balance has also contributed to the increase in fiscal space at the state level.

\section{Fiscal Imbalance: Inter-State Comparison}

However, there are sharp differences in the inter-State fiscal imbalance profile. In tables 1 and 2, States are ranked in terms of their level of fiscal and revenue deficits in three categories viz., high, medium and low taking average levels of fiscal and revenue deficit to GDP ratio from the period 2004-05 to 2008-09. Despite the reduction in fiscal imbalance, the States with large fiscal imbalance are West Bengal, Jharkhand, and Kerala. The states that are expected to generate revenue surplus are 8 , while state of Kerala and West Bengal would have a very high revenue deficits relative to other states. It needs to be emphasized that the states that have achieved fiscal deficit level below 3 percent of GSDP are those states having reasonably better history of management of state finances and fiscal prudence.

Table 1: Classification of States According to Level of Revenue Deficits and Their Changes: $2004-05$ to $2009-10$

\begin{tabular}{|l|l|l|l|l|}
\hline \multicolumn{5}{|c|}{ Classification of States according to Revenue Deficit } \\
\hline $\begin{array}{l}\text { Increasing at } \\
\text { high rate }\end{array}$ & High $\mathbf{2} \%$ & Medium $\mathbf{1} \%$ & \multicolumn{1}{|c|}{ Low $<\mathbf{1 \%}$} & Revenue Surplus \\
\hline $\begin{array}{l}\text { Increasing at } \\
\text { medium rate }\end{array}$ & & Punjab & $\begin{array}{l}\text { Haryana, } \\
\text { Maharashtra }\end{array}$ & Orissa \\
\hline $\begin{array}{l}\text { Increasing at } \\
\text { low rate }\end{array}$ & $\begin{array}{l}\text { West } \\
\text { Bengal, } \\
\text { Kerala }\end{array}$ & $\begin{array}{l}\text { Rajasthan, } \\
\text { Gujarat }\end{array}$ & Bihar \\
\hline
\end{tabular}

${ }^{4}$ The decline in interest burden is due to the softening of interest rates on government securities in the last couple of years. Also measure like debt swap schemes in a low interest regime has benefited the states in reducing the interest burden (Chakraborty: 2005). 


\begin{tabular}{|l|l|l|l|}
\hline & & & $\begin{array}{l}\text { Chhattisgarh, Goa, } \\
\text { Uttar Pradesh }\end{array}$ \\
\hline
\end{tabular}

Source: (Basic Data) Finance Accounts (various issues).

Table 2: Classification of States According to Level of Fiscal Deficits and Their Changes: 2004-05 to 2009-10

\begin{tabular}{|l|l|l|l|}
\hline \multicolumn{4}{|c|}{ Classification of States according to Fiscal Deficit } \\
\hline & \multicolumn{1}{|c|}{ High $>\mathbf{4} \%$} & \multicolumn{1}{c|}{ Medium $>\mathbf{3} \%$} & \multicolumn{1}{c|}{ Low } \\
\hline $\begin{array}{l}\text { Increasing at high } \\
\text { rate }\end{array}$ & & $\begin{array}{l}\text { Rajasthan, Goa, } \\
\text { Punjab }\end{array}$ & $\begin{array}{l}\text { Andhra Pradesh, } \\
\text { Bihar, Chhattisgarh, } \\
\text { Haryana, Karnataka, } \\
\text { Maharashtra, } \\
\text { Orissa, Tamil Nadu }\end{array}$ \\
\hline $\begin{array}{l}\text { Increasing at } \\
\text { medium rate }\end{array}$ & West Bengal & $\begin{array}{l}\text { Uttar Pradesh, } \\
\text { Kerala }\end{array}$ & $\begin{array}{l}\text { Gujarat, Madhya } \\
\text { Pradesh }\end{array}$ \\
\hline Increasing at low rate & Jharkhand & & \\
\hline
\end{tabular}

Source: Ibid.

It is important to examine how this fiscal balance is achieved. As mentioned earlier, this has happened in a low interest rate regime and also due to the improved revenue mobilization at centre as well as in the states. Transfers as a percentage of GDP has increased during the era of rule based fiscal control due to the higher growth of central revenues. The improvement in fiscal balance has been accompanied by a structural change in the share of revenues in combined revenues, where states' share has increased in the last couple of years (see, table 3). However, a similar trend has also been observed in case of revenue expenditures, where states' share in combined expenditure is on the increase. This points to the fact that the vertical fiscal gap may not have come down, if not widened despite higher vertical transfers due to increased revenue mobilization at the central level.

Table 3: Vertical Fiscal Imbalance: Recent Trends

\begin{tabular}{|c|c|c|c|c|c|c|c|c|c|c|c|}
\hline \multicolumn{12}{|c|}{ (In Percent) } \\
\hline & $\begin{array}{c}1990- \\
91\end{array}$ & $\begin{array}{c}2000- \\
01\end{array}$ & $\begin{array}{c}2002- \\
03\end{array}$ & $\begin{array}{c}\text { 2003- } \\
04\end{array}$ & $\begin{array}{c}\text { 2004- } \\
05\end{array}$ & $\begin{array}{c}\text { 2005- } \\
06\end{array}$ & $\begin{array}{c}\text { 2006- } \\
07\end{array}$ & $\begin{array}{c}\text { 2007- } \\
08\end{array}$ & $\begin{array}{c}2008- \\
09\end{array}$ & $\begin{array}{c}2009- \\
10 \\
\text { RE }\end{array}$ & $\begin{array}{c}2010- \\
11 \\
B E\end{array}$ \\
\hline $\begin{array}{l}\text { Centre's share } \\
\text { in combined } \\
\text { revenue }\end{array}$ & 55.39 & 55.07 & 54.90 & 53.31 & 51.84 & 49.98 & 49.86 & 53.72 & 51.02 & 48.33 & 49.20 \\
\hline $\begin{array}{l}\text { States' share in } \\
\text { combined } \\
\text { revenue }\end{array}$ & 63.21 & 63.37 & 62.31 & 62.21 & 61.24 & 62.44 & 61.96 & 58.52 & 61.93 & 64.52 & 62.76 \\
\hline $\begin{array}{l}\text { Centre's share } \\
\text { in combined } \\
\text { revenue } \\
\text { expenditure }\end{array}$ & 59.83 & 57.27 & 58.12 & 55.51 & 54.69 & 55.78 & 55.84 & 58.71 & 61.26 & 58.18 & 57.26 \\
\hline
\end{tabular}




\begin{tabular}{|l|c|c|c|c|c|c|c|c|c|c|c|}
\hline $\begin{array}{l}\text { States' share in } \\
\text { combined } \\
\text { revenue } \\
\text { expenditure }\end{array}$ & 55.19 & 56.03 & 54.31 & 56.27 & 56.28 & 55.17 & 55.33 & 53.48 & 49.30 & 51.64 & 52.64 \\
\hline
\end{tabular}

Source: Indian Public Finance Statistics 2010-11.

\section{Fiscal Consolidation and Equity}

Having examined the vertical imbalance, in this section we examine, whether the era of fiscal reforms and rule based fiscal control have helped in reducing the disparities in spending across states. Now all the states have FRA. Out of these states, except Karnataka, Kerala, Punjab and Uttar Pradesh, all other states have passed the FRA during the fiscal year 2005-06 with a uniform deficit reduction targets proposed by the $12^{\text {th }} \mathrm{FC}$. The rush to pass the FRA by the states is clearly driven by DCRF. Though at the aggregate level, there is a fiscal consolidation at the state level due to rule based fiscal control with revenue deficit coming close to zero and fiscal deficits below 3 per cent of GDP by the end of 2007-08, the outcome of such consolidation requires in-depth analysis of state finances. It is important to note that disparities in spending would ideally arise due to the disparity in revenues. As evident from the table 4, the coefficient of variations of per capita own revenues have increased over the years, while that of transfers declined. This in turn has resulted in an increase in disparities in per capita development spending. If we look at the Maximum to Minimum ratio of per capita own revenues and per capita expenditure, the divergence has increased over time.

Table 4: Coefficients of variations of Per Capita Own Revenues, Transfers and Developmental Spending Across States

\begin{tabular}{|l|r|r|r|r|r|r|r|r|}
\hline & $\begin{array}{c}\mathbf{1 9 9 0 -} \\
\mathbf{9 1}\end{array}$ & $\begin{array}{c}\mathbf{2 0 0 0 -} \\
\mathbf{0 1}\end{array}$ & $\begin{array}{c}\mathbf{2 0 0 4 -} \\
\mathbf{0 5}\end{array}$ & $\begin{array}{c}\mathbf{2 0 0 5 -} \\
\mathbf{0 6}\end{array}$ & $\begin{array}{c}\text { 2006- } \\
\mathbf{0 7}\end{array}$ & $\begin{array}{c}\mathbf{2 0 0 7 -} \\
\mathbf{0 8}\end{array}$ & $\begin{array}{c}\text { 2008- } \\
\mathbf{0 9}\end{array}$ & $\begin{array}{c}\text { 2009- } \\
\mathbf{1 0}\end{array}$ \\
\hline \multicolumn{8}{|c|}{ Coefficient of Variance } \\
\hline Own Revenues & 0.370 & 0.535 & 0.5147 & 0.5174 & 0.5139 & 0.5126 & 0.4477 & 0.4093 \\
\hline Transfers & 0.292 & 0.298 & 0.2850 & 0.1825 & 0.2000 & 0.2549 & 0.2380 & 0.2648 \\
\hline Development Exp. & 0.173 & 0.382 & 0.292 & 0.283 & 0.316 & 0.295 & 0.276 & 0.300 \\
\hline \multicolumn{8}{|c|}{ Maximum to Minimum Ratio } \\
\hline Own Revenues & 3.49 & 7.13 & 11.35 & 11.54 & 13.26 & 11.54 & 8.12 & 6.38 \\
\hline Transfers & 2.95 & 2.82 & 3.23 & 2.27 & 2.33 & 2.63 & 2.40 & 2.23 \\
\hline Development Exp. & 1.67 & 6.29 & 3.63 & 2.89 & 3.07 & 2.92 & 2.94 & 3.16 \\
\hline
\end{tabular}

Source: 1) Handbook of Statistics on State Finances 2010, RBI.

2) State Finances: A Study of Budgets, RBI (various issues).

There could be two reasons for this. One could be FRA related fiscal restraint in spending, the other could be central government's undertaking many of the functions through centrally sponsored schemes that are within the functional domain of the states. It is argued that as state expenditure is substituted by central spending through various 
implementing agencies bypassing the state budget, state budgetary spending on these sectors is coming down. Though critically important, we do not go into in this paper, the larger question whether such method of fund transfers bypassing the authority of the states is appropriate. ${ }^{5}$

\section{Fiscal Rule and Deficits \& Development Spending: An Econometric Investigation}

Using standard econometric techniques, this section aims at investigating the impact of fiscal rule on the fiscal performance of the Indian states. A panel dataset of 14 major non-special category states spread over 10 years, from 2000-01 to 2009-10, is used and this periodization is deliberate as this is a stable period with a mix of pre-rule based and post-rule based fiscal reform periods of state finances. A two-way fixedeffects model is used to serve the purpose of this study. The basic empirical specification is:

$F C_{i t}=\alpha+\beta I D_{i t}+\emptyset E D_{i t}+\lambda_{i}+\mu_{t}+v_{i t} ; i=1, \ldots, \mathrm{N}$, and $t=1_{, \ldots,}, \mathrm{T}$

where subscript $i$ stands for the Indian states and $t$ for the time-period. Vector $F C_{i t}$, the dependent variable, represents for the fiscal measures. Expenditure related fiscal measures are expressed in real per capita Indian rupees, ${ }^{6}$ whereas fiscal deficit is expressed as percentage of SGDP. All independent variables are divided into two groups: variables of interest and control variables. Per capita income growth and per capita income, proxied for business cycle and initial conditions respectively, and fiscal rule dummy constitute the group of variables of interest, vector $I D_{i t}$. Vector $E D_{\text {it }}$ represents for control variables such as dummy for the introduction of value added tax (VAT) at the state level, per capita intergovernmental (block) transfers, and effective rate of interest which may affect the fiscal outcomes. Usually, fiscal outcomes are found to be non-stationary. Assuming that the fiscal outcomes are non-stationary, first difference of all variables, but the binary ones, are used in the regression equation. State fixed effects, $\lambda_{\mathrm{i}}$, are included to account for unobserved state-specific factors, largely remain constant

${ }^{5}$ As mentioned by Rao (2007, p. 1253), this kind of transfers have been "undermining the role of systems and institutions in the transfer system. In fact, even under the transfers for state plans, normal assistance, which is given according to the Gadgil formula, constituted less than 48 per cent. Thus, we have a situation where the grants system has become predominantly purpose specific with a cobweb of conditionalities specified by various central ministries. Furthermore, quite a considerable proportion of grants which used to be given to the states now directly goes to autonomous agencies. This raises questions about the capacity to deliver public services by these autonomous agencies, mechanisms to augment the capacity and as the funds do not pass through states' consolidated funds, of accountability."

${ }^{6}$ All variables used in per capita are expressed at 1999-00 constant prices. 
over time, and time fixed effects, $\mu_{\mathrm{t}}$, are included to account for unobserved time-specific effects, common to all states.

Given the cross-sectional and time-series nature of the dataset, the standard ordinary least squares (OLS) assumption of independent and identically distributed errors is unlikely to be satisfied. Assuming that these estimation problems would occur, panelcorrecting standard errors (PCSE) and feasible generalized least squares (FGLS) estimation methods are used and the standard errors are corrected for heteroskedasticity and first ordered autocorrelation. The idea behind reporting results of two estimation methods is to show the robustness of the baseline findings across different estimation methods.

\section{Empirical Analysis}

Table 5 examines how the fiscal deficit of the Indian states has responded to business cycle, initial conditions, and fiscal rule during the period of our analysis. Results of the first two columns are estimated using PCSE estimation method and results of the last two columns are estimated using FGLS estimation method. Odd numbered columns display results when per capita income growth rate is used, whereas results estimated using per capita income are displayed in even numbered columns. Results suggest that neither growth rate nor per capita income has significant effect on fiscal deficit management in the Indian states. It is the introduction of fiscal rules which has successfully controlled the increasing fiscal deficit problems of the Indian states. Variables like growth rate and income would probably have an impact on the budget deficit in the long-run. Among the control variables, only increasing intergovernmental transfers has helped the Indian states to reduce their fiscal deficit.

In the recent decades, increasing fiscal deficits in India is found to be largely driven by the poor management of revenue deficit. How is the revenue deficit managed at the state level in the post fiscal rule era is also examined in this study and the results are presented in table 6 . The result suggests that the introduction of fiscal rule has reduced the level of revenue deficit of the Indian states, and in turn, it has helped them in reducing the size of fiscal deficit. Apart from fiscal rule, intergovernmental transfer and effective interest rate have significant impacts on revenue deficit. Increasing transfers reduce the revenue deficit, whereas an increase in interest rate increases the revenue deficit. 
Table 5: Determinants of Fiscal Deficit

\begin{tabular}{|l|c|c|c|c|}
\hline \multirow{2}{*}{} & \multicolumn{2}{|c|}{ PCSE } & \multicolumn{2}{c|}{ GLS } \\
\cline { 2 - 5 } & $\mathbf{( 1 )}$ & $\mathbf{( 2 )}$ & $\mathbf{( 3 )}$ & $\mathbf{( 4 )}$ \\
\hline Growth rate & 0.025 & - & 0.025 & - \\
\hline Per capita income & $(0.024)$ & - & $(0.02)$ & -0.001 \\
& - & -0.001 & - & $(0.001)$ \\
\hline FRBM rule dummy & & $(0.001)$ & & $-0.624^{*}$ \\
& $-0.668^{* *}$ & $-0.624^{*}$ & $-0.668^{*}$ & $(0.349)$ \\
\hline VAT dummy & $(0.332)$ & $(0.333)$ & $(0.352)$ & 0.242 \\
& 0.31 & 0.242 & 0.031 & $(0.397)$ \\
\hline Intergovernmental transfers & $(0.425)$ & $(0.405)$ & $(0.399)$ & $-0.003^{* * *}$ \\
& $-0.003^{* * *}$ & $-0.003^{* * *}$ & $-0.003^{* * *}$ & $(0.001)$ \\
\hline Effective interest rate & $(0.001)$ & $(0.001)$ & $(0.001)$ & 0.116 \\
& 0.136 & 0.116 & 0.136 & $(0.087)$ \\
\hline Constant & $(0.115)$ & $(0.113)$ & $(0.089)$ & 0.539 \\
& 0.297 & 0.539 & 0.297 & $(0.628)$ \\
\hline State Effects & $(0.501)$ & $(0.541)$ & $(0.6)$ & Yes \\
\hline Time Effects & Yes & Yes & Yes & Yes \\
\hline R-squared & Yes & Yes & Yes & - \\
\hline Wald chi-square & 0.49 & 0.49 & - & $133^{* * *}$ \\
\hline Number of observations & $2821^{* * *}$ & $3111^{* * *}$ & $132^{* * *}$ & 140 \\
\hline Number of groups & 140 & 140 & 140 & 14 \\
\hline Notes: Pan & 14 & 14 & 14 & \\
\hline
\end{tabular}

Notes: Panel specific AR(1) standard errors are shown in parentheses. ${ }^{* * *} p<0.01 ;{ }^{* *} p<0.05 ;$ and ${ }^{*} p<0.1$

Table 6: Determinants of Revenue Deficit

\begin{tabular}{|l|c|c|c|c|}
\hline & \multicolumn{2}{|c|}{ PCSE } & \multicolumn{2}{c|}{ GLS } \\
\hline & $\mathbf{( 1 )}$ & $\mathbf{( 2 )}$ & $\mathbf{( 3 )}$ & $\mathbf{( 4 )}$ \\
\hline Per capita income growth & 0.018 & - & 0.018 & - \\
rate & $(0.02)$ & & $(0.021)$ & -0.001 \\
\hline Per capita income & - & -0.001 & - & $(0.001)$ \\
\hline FRBM rule dummy & & $(0.001)$ & & $-0.607^{\star}$ \\
& $-0.633^{*}$ & $-0.607^{\star}$ & $-0.633^{*}$ & $(0.319)$ \\
\hline VAT dummy & $(0.338)$ & $(0.331)$ & $(0.325)$ & 0.12 \\
& 0.158 & 0.12 & 0.158 & $(0.351)$ \\
\hline Intergovernmental transfers & $(0.437)$ & $(0.451)$ & $(0.35)$ & $-0.0016^{*}$ \\
& $-0.002^{\star *}$ & $-0.002^{* *}$ & $-0.002^{\star *}$ & $-0.0009)$ \\
\hline Effective interest rate & $(0.001)$ & $(0.001)$ & $(0.001)$ & $(0.000)^{*}$ \\
\hline
\end{tabular}




\begin{tabular}{|l|c|c|c|c|}
\hline & $(0.097)$ & $(0.096)$ & $(0.084)$ & $(0.083)$ \\
\hline Constant & $0.898^{*}$ & $1.096^{*}$ & 0.898 & $1.096^{*}$ \\
& $(0.497)$ & $(0.592)$ & $(0.555)$ & $(0.584)$ \\
\hline State Effects & Yes & Yes & Yes & Yes \\
\hline Time Effects & Yes & Yes & Yes & Yes \\
\hline R-squared & 0.51 & 0.51 & - & - \\
\hline Wald chi-square & $4735^{\text {** }}$ & $4555^{\text {***}}$ & $143^{\text {***}}$ & $143^{\text {***}}$ \\
\hline Number of observations & 140 & 140 & 140 & 140 \\
\hline Number of groups & 14 & 14 & 14 & 14 \\
\hline
\end{tabular}

Note: See notes to table 5.

Findings of previous tables document the fact that adoption of fiscal rule has helped the Indian states in reducing their deficits. Continuing our analysis further, we intend to identify how Indian states have reduced their fiscal deficits and where the adjustment has been made, particularly in the light of the findings on fiscal rule. Adjustments could have been made either by reducing the size of public expenditure or by increasing the revenue collection or a combination of both. However, the size of revenue collection is less likely to change in short-run. Hence, expenditure items appear to be the most likely candidates where the necessary adjustments have been done to meet the FRBM deficit targets. To check these possibilities, we have followed a twostepped top-down approach to analyse our results. In the first step, we have examined how total expenditure has responded to fiscal rules. In the second step, we have focused on disaggregated expenditure measures to find the exact source of adjustment within total expenditure.

Table 7 displays the results of total expenditure. Per capita income has a positive and significant effect on the size of total expenditure, whereas growth rate does not have a significant effect on it. It suggests that the richer states are also having larger government size compared to poorer states. Negative and significant fiscal rule variable indicates that the path of 'spending cuts' is followed by the states to meet the FRBM deficit targets. Among the control variables, only the increases in block transfers contribute to the size of total expenditure positively and significantly. 
Table 7: Determinants of Total Expenditure

\begin{tabular}{|c|c|c|c|c|}
\hline & \multicolumn{2}{|c|}{ PCSE } & \multicolumn{2}{|c|}{ GLS } \\
\hline & (1) & (2) & (3) & (4) \\
\hline $\begin{array}{l}\text { Per capita income growth } \\
\text { rate }\end{array}$ & $\begin{array}{c}6.295 \\
(4.256) \\
\end{array}$ & - & $\begin{array}{l}6.295 \\
(4.869) \\
\end{array}$ & - \\
\hline Per capita income & 4 & $\begin{array}{c}0.1^{* \star *} \\
(0.028)\end{array}$ & 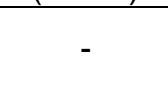 & $\begin{array}{c}0.1^{* \star *} \\
(0.023)\end{array}$ \\
\hline FRBM rule dummy & $\begin{array}{c}-164.13^{* *} \\
(73.05)\end{array}$ & $\begin{array}{c}-157.07^{* *} \\
(73.37)\end{array}$ & $\begin{array}{c}-164.13^{*} \\
(86.21)\end{array}$ & $\begin{array}{c}-157.07^{* *} \\
(79.24)\end{array}$ \\
\hline VAT dummy & $\begin{array}{l}-56.98 \\
(104.8)\end{array}$ & $\begin{array}{l}-22.51 \\
(91.52)\end{array}$ & $\begin{array}{c}-56.98 \\
(87.47)\end{array}$ & $\begin{array}{l}-22.51 \\
(85.81)\end{array}$ \\
\hline Intergovernmental transfers & $\begin{array}{l}0.574^{\star *} \\
(0.235)\end{array}$ & $\begin{array}{l}0.541^{\star * \star} \\
(0.202)\end{array}$ & $\begin{array}{l}0.574^{* * *} \\
(0.21)\end{array}$ & $\begin{array}{l}0.541^{* \star *} \\
(0.197)\end{array}$ \\
\hline Effective interest rate & $\begin{array}{l}10.39 \\
(21.51)\end{array}$ & $\begin{array}{c}5.639 \\
(19.66)\end{array}$ & $\begin{array}{c}10.39 \\
(21.26)\end{array}$ & $\begin{array}{c}5.639 \\
(19.71)\end{array}$ \\
\hline Constant & $\begin{array}{l}360.85^{\star * *} \\
(118.77)\end{array}$ & $\begin{array}{c}156.61 \\
(125.28)\end{array}$ & $\begin{array}{l}360.85^{\star \star \star} \\
(139.61)\end{array}$ & $\begin{array}{l}156.61 \\
(138.8)\end{array}$ \\
\hline State Effects & Yes & Yes & Yes & Yes \\
\hline Time Effects & Yes & Yes & Yes & Yes \\
\hline R-squared & 0.4 & 0.44 & - & - \\
\hline Wald chi-square & $6099^{* \star *}$ & $2455^{\star \star \star}$ & $77^{\star \star \star}$ & $97^{\star \star \star}$ \\
\hline Number of observations & 140 & 140 & 140 & 140 \\
\hline Number of groups & 14 & 14 & 14 & 14 \\
\hline
\end{tabular}

Notes: Panel specific AR(1) standard errors are shown in parentheses. ${ }^{* \star *} p<0.01 ;{ }^{* *} p<0.05 ;$ and ${ }^{*} p<0.1$

In the short run, not all expenditure items allow a government to make adjustments to meet deficit targets. Expenditure items such as interest payment, and paying wages, salaries and pension are unavoidable in nature and these items are accounted under non-development expenditure. Reducing the size of non-development expenditure does not seem to be a feasible option for a government, not at least in the short-run. Development expenditure, constitutes largely spending on health and education, appears to be the item where a government is more likely to adjust to achieve deficit targets. To test this possibility, we have estimated results of development expenditure and they are reported in table 8.

Like in the case of total expenditure, income level of a state, not the growth rate, seems to be playing a significant role in determining the size of development expenditure. Fiscal rule dummy has a significant and negative impact on development expenditure and it suggests that the Indian states have compressed their development expenditure in post 
FRBM period. Again, like total expenditure, block transfers have a positive and significant impact on development expenditure.

Table 8: Determinants of Development Expenditure

\begin{tabular}{|c|c|c|c|c|}
\hline & \multicolumn{2}{|c|}{ PCSE } & \multicolumn{2}{|c|}{ GLS } \\
\hline & (1) & (2) & (3) & (4) \\
\hline $\begin{array}{l}\text { Per capita income growth } \\
\text { rate }\end{array}$ & $\begin{array}{l}4.837 \\
(4.12)\end{array}$ & - & $\begin{array}{l}4.837 \\
(4.66)\end{array}$ & - \\
\hline Per capita income & - & $\begin{array}{c}0.093^{\star * *} \\
(0.027)\end{array}$ & 1 & $\begin{array}{c}0.093^{\star * *} \\
(0.022)\end{array}$ \\
\hline FRBM rule dummy & $\begin{array}{c}-138.12^{\star \star} \\
(54.53)\end{array}$ & $\begin{array}{c}-151.26^{* * *} \\
(58.86)\end{array}$ & $\begin{array}{c}-138.12^{*} \\
(80.35)\end{array}$ & $\begin{array}{c}-151.26^{* \star} \\
(75.48)\end{array}$ \\
\hline VAT dummy & $\begin{array}{l}-26.81 \\
(104.7)\end{array}$ & $\begin{array}{l}-0.759 \\
(93.71)\end{array}$ & $\begin{array}{l}-26.81 \\
(87.97)\end{array}$ & $\begin{array}{c}-0.759 \\
(86.87)\end{array}$ \\
\hline Intergovernmental transfers & $\begin{array}{l}0.454^{*} \\
(0.254)\end{array}$ & $\begin{array}{l}0.389^{*} \\
(0.218)\end{array}$ & $\begin{array}{l}0.454^{* *} \\
(0.209)\end{array}$ & $\begin{array}{l}0.389^{* *} \\
(0.197)\end{array}$ \\
\hline Effective interest rate & $\begin{array}{l}-15.11 \\
(21.49)\end{array}$ & $\begin{array}{l}-18.93 \\
(19.69)\end{array}$ & $\begin{array}{l}-15.11 \\
(20.87)\end{array}$ & $\begin{array}{l}-18.93 \\
(19.27)\end{array}$ \\
\hline Constant & $\begin{array}{c}165.1 \\
(118.8)\end{array}$ & $\begin{array}{c}22.3 \\
(124.01)\end{array}$ & $\begin{array}{c}165.1 \\
(133.3)\end{array}$ & $\begin{array}{c}22.3 \\
(135.04)\end{array}$ \\
\hline State Effects & Yes & Yes & Yes & Yes \\
\hline Time Effects & Yes & Yes & Yes & Yes \\
\hline R-squared & 0.42 & 0.45 & - & - \\
\hline Wald chi-square & $6793^{\star \star \star}$ & $6268^{\star \star \star}$ & $92^{\star \star \star}$ & $110^{\star \star \star}$ \\
\hline Number of observations & 140 & 140 & 140 & 140 \\
\hline Number of groups & 14 & 14 & 14 & 14 \\
\hline
\end{tabular}

Notes: See notes to table 7.

In the recent years, the centre has introduced various centrally sponsored schemes such as Mahatma Gandhi National Rural Employment Guarantee Act (MGNREGA) to create rural employment, Sarva Shiksha Abhiyan (SSA), and National Rural Health Mission (NRHM) to improve education and health spending. These spending are not reported in the state budgets. It is quite possible that, as a result of such centrally sponsored schemes, which are development expenditure in nature, some of the states might have reduced their own development spending in the era of fiscal rules. To check this possibility, we have added the spending incurred on centrally sponsored schemes with states' own development expenditure, reported in the budget, and reestimated the results. ${ }^{7}$ The results are reported in table 9 and they are similar to the results of development expenditure in all aspects (i.e. reported in table 8). It reaffirms the

\footnotetext{
${ }^{7}$ State-wise data on MGNREGA spending is not available before 2009-10. Hence, we have taken state-wise spending figures available only for SSA and NRHM since 2005-06.
} 
fact that the Indian states have used the strategy of cutting down development expenditure to achieve the deficit targets as per the FRBM rule.

Table 9: Determinants of Development Expenditure (Including off-budget expenditure)

\begin{tabular}{|c|c|c|c|c|}
\hline & \multicolumn{2}{|c|}{ PCSE } & \multicolumn{2}{|c|}{ GLS } \\
\hline & (1) & (2) & (3) & (4) \\
\hline $\begin{array}{l}\text { Per capita income growth } \\
\text { rate }\end{array}$ & $\begin{array}{c}4.821 \\
(4.195)\end{array}$ & - & $\begin{array}{c}4.821 \\
(4.788)\end{array}$ & - \\
\hline Per capita income & - & $\begin{array}{l}0.093^{\star \star \star} \\
(0.028)\end{array}$ & - & $\begin{array}{c}0.093^{\star \star \star} \\
(0.023)\end{array}$ \\
\hline FRBM rule dummy & $\begin{array}{c}-138.77^{* *} \\
(55.95)\end{array}$ & $\begin{array}{l}-150.31^{* *} \\
(60.12)\end{array}$ & $\begin{array}{c}-138.77^{*} \\
(80.3)\end{array}$ & $\begin{array}{l}-150.31^{* *} \\
(75.62)\end{array}$ \\
\hline VAT dummy & $\begin{array}{l}-33.21 \\
(106.1)\end{array}$ & $\begin{array}{l}-13.65 \\
(93.99)\end{array}$ & $\begin{array}{r}-33.21 \\
(88.21)\end{array}$ & $\begin{array}{l}-13.65 \\
(87.02)\end{array}$ \\
\hline Intergovernmental transfers & $\begin{array}{l}0.478^{*} \\
(0.258)\end{array}$ & $\begin{array}{l}0.405^{*} \\
(0.22)\end{array}$ & $\begin{array}{l}0.478^{* *} \\
(0.21)\end{array}$ & $\begin{array}{l}0.405^{\star \star} \\
(0.198)\end{array}$ \\
\hline Effective interest rate & $\begin{array}{l}-16.36 \\
(21.35)\end{array}$ & $\begin{array}{l}-19.79 \\
(19.56)\end{array}$ & $\begin{array}{l}-16.36 \\
(20.91)\end{array}$ & $\begin{array}{l}-19.79 \\
(19.32)\end{array}$ \\
\hline Constant & $\begin{array}{c}162.7 \\
(119.2)\end{array}$ & $\begin{array}{c}18.98 \\
(123.57)\end{array}$ & $\begin{array}{c}162.7 \\
(133.4)\end{array}$ & $\begin{array}{c}18.98 \\
(135.11)\end{array}$ \\
\hline State Effects & Yes & Yes & Yes & Yes \\
\hline Time Effects & Yes & Yes & Yes & Yes \\
\hline R-squared & 0.44 & 0.47 & - & - \\
\hline Wald chi-square & $8125^{\star \star *}$ & $7093^{\star * *}$ & $100^{\star \star *}$ & $118^{* \star \star}$ \\
\hline Number of observations & 140 & 140 & 140 & 140 \\
\hline Number of groups & 14 & 14 & 14 & 14 \\
\hline
\end{tabular}

Notes: See notes to table 7.

To conclude, our findings suggest that the introduction of fiscal rule has helped the Indian states in reducing their fiscal deficit. It also shows that the reduction in fiscal deficit is achieved by reducing the size of revenue deficit. A more detailed investigation reveals the fact that the deficit targets are achieved by following the path of spending cuts, largely by reducing spending for development purposes.

\section{Conclusions}

To conclude, it needs to be emphasized that fiscal reforms have largely been revenue driven via growth. Although, there has been an improvement in the aggregate fiscal position of the states till 2007-08, there has been disparities in fiscal performance across states. Increasing disparities in per-capita spending has increased in recent years. 
The econometric exercise reveals that the state level fiscal policy and fiscal rule has been successful in reducing fiscal imbalance even when we control for other policy shocks and other standard determinants of fiscal balance. However, it is clear that fiscal targets under fiscal rule have been achieved through a cut in discretionary development spending. Our econometric exercise shows that cut in spending has been partially offset by higher central transfers. Had this not been the case, the state level contraction in development spending would have been even higher to comply with the rule. 


\section{References}

Alesina, A., and T. Bayoumi, 1996. "The Costs and Benefits of Fiscal Rules: Evidence from U.S. States". NBER Working Paper No. 5614.

Auerbach, A., 2008. "Federal Budget Rules: The US Experience". NBER Working Paper, No. 14288.

Ballabriga, F., and C. Martinez-Mongay, 2003. "Has EMU Shifted Monetary and Fiscal Policies?" In M. Buti (ed.) Monetary and Fiscal Policies in EMU: Interactions and Coordination, Cambridge University Press, Cambridge.

Chakraborty, P., 2005. "Debt Swap in Low Interest Rate Regime: Unequal Gains and Future Worries". Economic and Political Weekly, 40; 4357-4362.

Claeys, P., 2008. "Rules, and Their Effects on Fiscal Policy in Sweden". Swedish Economic Policy Review, 15; 7-47.

Dupont, J., and K. Kwarteng, 2012. "Binding the Hands of Government - a Credible Fiscal Rule for the UK”. IEA Current Controversies Paper No. 36.

Galí, J., and R. Perotti, 2003. "Fiscal Policy and Monetary Integration in Europe". Economic Policy 37; 535-572.

Kopits, G. 2001. "Fiscal Rules: Useful Policy Framework or Unnecessary Ornament?" IMF Working Paper, WP/01/145.

Lane, P. 2003. "The Cyclical Behavior of Fiscal Policy: Evidence from the OECD". Journal of Public Economics 87(12); 2661-2695.

Lee, Y., and T. Sung, 2007. "Fiscal Policy, Business Cycles and Economic Stabilisation: Evidence from Industrialised and Developing Countries". Fiscal Studies 28(4); pp. 437-462.

Marneffe, W., B. Aarle, W. Wielen, and L. Vereeck, 2010. "The Impact of Fiscal Rules on Public Finances: Theory and Empirical Evidence for the Euro Area". CESifo Working Paper No. 3303.

Milesi-Ferretti, G., 1996. "Fiscal Rules and the Budget Process". IMF Working Paper No. $96 / 60$. 
Millar, J., 1997. "The Effects of Budget Rules on Fiscal Performance and Macroeconomic Stabilization". Bank of Canada Working Paper 97-15.

Poterba, J., 1997. "Do Budget Rules Work?” In A. Auerbach (ed.), Fiscal Policy: Lessons from Economic Research, MIT Press, Cambridge, MA.

Rao, M. G., 2007. "Fiscal Adjustment: Rhetoric and Reality", Economic and Political Weekly, 42 (14); 1252-1257.

Rao, M., and P. Chakraborty, 2006. "Multilateral Adjustment Lending to States in India: Hastening Fiscal Correction or Softening the Budget Constraint?" Journal of International Trade and Economic Development, 15(3); 335-358.

Tapsoba, R., 2012. "Do National Numerical Fiscal Rules Really Shape Fiscal Behaviours in Developing Countries? A Treatment Effect Evaluation". Economic Modelling. 19(4); 1356-1369.

Viren, M., 2002. "Do the OECD Countries Follow the Same Fiscal Policy Rule?". in (eds.)M. Buti et al., The Behaviour of Fiscal Authorities, Stabilisation, Growth and Institutions, Palgrave Press, London. 